Professor Władysław Zuziak, PhD, https:// orcid.org/0000-0002-0483-0533

Faculty of Philosophy

Pontifical University of John Paul II

in Krakow

\title{
Jean-Paul Sartre and Louis Lavelle - Two Existential Conceptions of Humanism and their Ethical Consequences
}

\author{
Jean-Paul Sartre i Louis Lavelle - dwie egzystencjalne koncepcje \\ humanizmu i ich konsekwencje etyczne ${ }^{1}$
}

https:/ / doi.org/10.34766/ fetr.v48i4.977

\begin{abstract}
On the basis of the thesis "existence precedes the essence", L. Lavelle and J.-P. Sartre developed two different versions of existentialism which were the foundation for creating different models of humanism based on the phenomenological approach. I attempt to show that Sartre's atheistic existentialism, which relies on the abstract conception of freedom and an erroneous project of man, is a theory which is less plausible than the existentialism of Lavelle, based on the assumption of man's participation in being. I also discuss the ethical consequences for individual and social development that result from the assumptions of both conceptions.

Keywords: axiology, authenticity, freedom, humanism, participation in Being.
\end{abstract}

Abstrakt: Opierając się na tezie, że „istnienie poprzedza istotę”, L. Lavelle i J.-P. Sartre opracowali dwie różne wersje egzystencjalizmu, które stały się podstawą do stworzenia różnych modeli humanizmu, bazujących na podejściu fenomenologicznym. Próbuję pokazać, że ateistyczny egzystencjalizm Sartre'a, opiera się na abstrakcyjnej koncepcji wolności i, co staram się uzasadnić, błędnym projekcie człowieka, co sprawia, że w moim przekonaniu, jest teorią trudniejszą do przyjęcia niż egzystencjalizm Lavelle'a oparty na założeniu udziału człowieka w byciu. Omawiam również konsekwencje dla rozwoju indywidualnego i społecznego, jakie w wymiarze etycznym wynikają z założeń obu koncepcji.

Słowa kluczowe: aksjologia, autentyczność, humanizm, uczestnictwo w bycie, wolność.

\section{Introductory Remarks}

Louis Lavelle and Jean-Paul Sartre are two outstanding 20th-century existentialists. The starting point of their conceptions was the thesis that "existence precedes the essence", which was formulated by Lavelle and extended by Sartre. Generally speaking, this thesis can be understood in such a way that a human being can arrive at the definition of his essence what/who he is. Of course, they both differed in detail, which resulted from different visions of the world and man, but they both stressed that with existence there comes a world of

\footnotetext{
${ }^{1}$ Artykuł w języku polskim dostępny jest na stronie:

https://www.stowarzyszeniefidesetratio.pl/Presentations0/2021-4Zuzi2.pdf
} 
values: "Human reality is what made the value appear in the world" (Sartre 2007, p. 139). We live and therefore we must make choices - in this way we discover the world of values that we organize according to our preferences and plans.

For both philosophers, existential conceptions were the basis for developing their own, radically different, models of humanism. Although they both agreed that "Humanism can be understood as a theory that regards man as a goal and the highest value" (Sartre 1998, p. 79), for Sartre, this humanism took a radical form, opposing any form of human determination. For Lavelle, humanism had a less radical dimension, which resulted from a different understanding of freedom. They both sought to define what authentic being is and how one should "purify" existence so that a human being can live authentically in accordance with his/her calling. Both philosophers also show a phenomenological approach in their considerations about existence and freedom, although the term "phenomenology" itself is not present.

Despite similar assumptions and goals, both conceptions differ greatly in their diagnoses and conclusions. The consequences of the solutions that they proposed are also radically different. Because these consequences have a practical dimension, they affect the current vision of the world and the perception of man's place in the world, it is worth comparing both models of existentialism and the resulting visions of humanism.

The aim of the article is to indicate that Lavelle's forgotten concept may be more inspiring and "useful" for the development of our culture than Sartre's early philosophical projects formulated before the publication of Cahiers pour une morale, which are now more well-known and more widely present in our social consciousness.

\section{The Basic Difference - Freedom}

Both philosophers agreed that existence "abandoned in the world, imprisoned in its own loneliness and unable to break it, not knowing its origin, condemned to an incomprehensible fate and certain of only one thing, namely being condemned to death, which one day will consume it" (Lavelle 1947, p. 34) must find some meaning of life. And they both tried to sketch their own vision of this meaning. They claimed that the human being could create himself to some extent by finding the sense of existence.

For both philosophers, essence is a task whereas the role of existence is to "form oneself or at least to have the possibility of forming oneself, that is, of being capable of acquiring essence" (Lavelle 1946, p. 102). Essence is not given to autonomous being in the same way as things and everything that preserves memory because essence is a possibility, and not necessarily the only one, "the essence is our possibilities recognized and put into action" (Lavelle 1946, p. 107). Therefore, the essence always remains only a sketch of the Self 
supplemented by successive experiences and perspectives that appear every time we take an action.

Sartre emphasized that "I exist as my unconditional freedom and I am my own project in its independence" (1983 p. 267)2. Man in this conception is - or rather can be - the absolute master of his own development, provided that he frees himself from all determinants. On the other hand, as J. Ecole emphasized, "in Lavelle's conception man is not nothing in the first place, to become something that he creates by himself, as was suggested by Sartre. For Lavelle the opportunity given to man by existence is not to get out of nothingness, but to discover and realize his essence, that is, accept and develop it, by using the possibilities that are in him before he even is aware of them" (1952, p. 388). As one can see, the difference in the understanding of man between the two philosophers is fundamental, and at its root lies a different understanding of freedom.

Sartre wrote: "What is missing from man? Being his own foundation. By what and in what does this lack occur? In freedom and through it. For freedom is that very foundation" (Sartre 1983, p. 455). In Sartre's conviction, the foundation of the world is created by a human being, which is freedom itself establishing the basis of its existence. Aware of his agency, he notices that even "an action that appears to be a subtle compulsion also turns out to be unnecessary and would not have to be done at all. When we do it, it is our own choice and it is a free choice" (Sartre 2005, p. 41). This choice leads to a gradual liberation from the inauthentic-world-existence.

For Sartre, freedom is an absolute value: "Either man is completely determined (which is unacceptable, primarily because determined consciousness, i.e., motivated from the outside, becomes pure externality and ceases to be consciousness), or man is absolutely free" (Sartre 2007, p. 544).With this understanding of freedom, the formula "existence precedes the essence" means that "man is primarily a subjectively lived project instead of being foam, mold or cauliflower. Nothing previously exists before this project" (Sartre 1998, p. 27-28). The belief that "man must create his own essence" means that he "will become what he makes of himself" (Sartre 1998, p. 27). Man creates himself "out of nothing", from scratch; his essence is not outside the project that he establishes by himself. This lack of determination, both at the point of departure and the point of arrival (because "unreal" death does not limit $\mathrm{him}^{3}$ ) gives him total, "divine" freedom and omnipotence - man takes the place of God.

The consequence of Sartre's freedom is the lack of any orders, but also the lack of any guidelines. There is no help from anywhere: "If God does not exist, we do not see before us the values or orders that would justify our behavior. So we have neither in ourselves nor in

${ }^{2}$ All translations of the original text Cahiers pour une morale. Paris: Gallimard, 1983 are my own. The paper was prepared thanks to the "Excellent Science” program (DNK/SN/466899/2020) of the MNiSW (actually the MEiN) of Poland, by the name „(Ir)relevance of Phenomenology? (Im)pertinence de la phénoménologie?".

3 "In being-for-oneself there is no room for death" (Sartre, 2007, p. 671). 
front of us of any confirmation or justification in the field of higher values. We are alone, nobody will justify us. I would like to express it by saying that man is condemned to freedom" (Sartre 1998, p. 38-39). "Condemned" - because freedom is not just a task. According to Sartre's later works, full liberation becomes a curse. Paradoxically, a man who was to be the measure of all things, now reduced to himself and left alone becomes an unnecessary, incomprehensible burden for himself.

In this conception, no one can expect any help from others. Another man, according to Sartre, is a threat to absolute, individual freedom: "He is a freedom set against me, a freedom whose thought and will can approve or oppose me" (Sartre 1998, p. 61), thus he sets the limits of my freedom and remains a competitive carrier of his own absolute freedom. Adopting the point of view of the other is a defeat of one's freedom. His presence makes it difficult or even impossible to become oneself and compels to hatred (Sartre 2007, p. 506507). Thus, there can be only one conclusion: we create ourselves in the fight against other entities (Sartre 2007, p. 527). The opponent judges me, limits my freedom, manipulates it, and destroys it. He cannot know who I am, so he reduces me to his own perception.

Sartre's freedom, freeing man from all coercion, deprives him of all hope. He equips man with absolute but absurd freedom whereas Lavelle's freedom boils down to using the possibilities offered by Being, both in the external dimension and in the individual dimension, by recognizing by man his own potential: "Freedom, then, is not a lack of determination, but a gift by which we are called to make ourselves what we are" (Lavelle 1955, p. 224).

Freedom, in Lavelle's conviction, is not only a value, but also a condition for the emergence and manifestation of any other value in human existence. The act of affirming values is performed by a free turn towards what is valuable: "This consent expresses in a unique way a characteristic act of our freedom" (Lavelle 1948, p. 145). We are not forced to be free, because we can voluntarily turn away from freedom, which many people, in fact, do. Freedom carries out and maintains a kind of balance between grace, which man does not always respond to, and a necessity to which he is sometimes coerced (Lavelle, 1946, p. 91). By grace we should understand the possibilities offered to our freedom by the dynamic Being.

Moreover, freedom is not the primordial state of the existing self, but gaining freedom is a reflective process and, as Lavelle emphasizes: "there is a kind of proportionality between degrees of freedom and degrees of consciousness" (Lavelle, 1946, p. 341; 1948, p. 141; 1955, p. 201). Lavelle understands freedom broadly and analyzes its various aspects: "freedom of thought stays in touch with experience without which it would be devoid of matter, freedom of will is desire without which it would be without momentum, and freedom of love is a kind of affection without which it would be devoid of enthusiasm and tenderness" (Lavelle, 1946, p. 341). He understands freedom as a break with nature, but he is 
talking about the process of overcoming bodily nature: "In the course of our existence, the proper task of freedom is to make us a specifically spiritual being, that is, one who, freeing himself from the past, is constantly creating his own reason for action" (Lavelle, 1955, p. 209). Finding the "essence" is associated with achieving "spiritual and personal freedom, that is, the possibility of self-determination in an uninterrupted internal process" (Lavelle, 1951, vol. I, p. 739).

Freedom is the first step on the road to self-ownership, although to some extent it is a break with nature, with "desires and possibilities that are in me" (Lavelle, 1948, p. 234), it constantly remains in connection with this nature that "provides the materials it needs and the powers at its disposal" (Lavelle, 1948, p. 234). In this conception freedom cannot do without nature. What is more, "it must be completely immersed in reality, so as not to be just a pure possibility" (Lavelle, 1948, p. 167).

Reality - already fulfilled and defined - limits the subjective act of participation and creative activity of the subject. However, as Lavelle emphasized, thanks to spiritual development in the human world there is room for real and concrete freedom. Such freedom does not have to be definable, but it can be expressed through our emotionally oriented action and thinking. Emphasizing the importance of emotions in shaping the intellectual and spiritual sphere was another important merit of Lavelle who struggled in his works with positivistic absolutization of reason. Sartre and his many successors did not resist this rationalist intellectualism shaped by the Enlightenment.

\section{Authenticity}

One of the main goals of existentialism was to purify consciousness from the obstacles on the road to achieving man's authenticity. Considering the issue of authenticity, Lavelle and Sartre addressed the problem that was signaled by F. Nietzsche who tried to sensitize us to the "fragrance of authenticity" (Nietzsche, 1911, p. 434), but did not decide how this authenticity should be understood. Before Nietzsche, this problem also appeared in the work of the precursor of existentialism, S. Kierkegaard. Later H. Bergson made an attempt to define authenticity as a kind of identity of personality and action, comparing it to "hard to define similarities that can be found between an author and his works" (Bergson, 1904, p. 113).

Following in the footsteps of Bergson, Sartre and Lavelle recognized full commitment to fulfilling the accepted "project" as a measure of authenticity. Of course, they both emphasized that the project must exceed the current conditions that impose concrete choices and lead us in certain ways. We have a choice, either to give in to "nature", i.e., actualized external determinants, or - against everything that limits us - to strive to fulfill ourselves. For both, it was obvious that man is or at least may become the creator of value and 
meaning. Thus, he can create a model of action in which he fully consciously acts in accordance with his own source choices and accepts himself and all the consequences of being himself. In such model there is full harmony between the project, selection acts, and its activities, and all the possibilities could be used to the fullest extent. An undeniable inspiration for these ideas was Nietzsche's superman. The will of power is interpreted here, just like in The Joyful Wisdom, as the will to develop (Cf. Nietzsche, 1907, p. 301). And in both cases Nietzsche's answer to the question "What is good?" - remains valid - "everything that increases man's feeling of power, the will of power and the power itself" (Nietzsche, 1907, p. 6).

Increasing one' own power, self-improvement, the development of one's own potential, by using all the possibilities constitute, according to Lavelle, the determinants of an authentic man who makes his/her destiny come into being" ${ }^{4}$. As an opposite, negative option Lavelle describes Narcissus who commits his greatest sin towards himself and Being when he turns away from the possibility of increasing his own power and focuses on what he has already achieved. He rejects responsibility for himself, for striving for further development, for self-realization. Turning away from such realization is tantamount to falling into inauthenticity, pretending to be someone you are not, or stopping at some stage of development. For Lavelle, stopping in development is a "Narcissus' mistake," a mistake of neglect, even a sin, towards our own existence and towards Being in which we participate. This involves recognizing responsibility for the gifts-opportunities received from Being.

Sartre, in turn, argued that freedom means that each of us "carries the weight of the world on his shoulders" and is "responsible for the world, for himself in his way of being" (Sartre, 2007, p. 639). However, it seems that such an overwhelming responsibility for himself and the world in Sartre's conception has no real basis. It is much better justified in Lavelle's concept of participation. The consent to actively participate in the encompassing Being is certainly a more credible motive for accepting such responsibility. It is worth noting the dynamic nature of being in Lavelle's concept which precedes Heidegger's distinction between Being and being (Cf. Heidegger, 1977, p. 86).

Based on Sartre's assumptions, it is also difficult to justify the very need for man's development. Not having a "point of support", what can he rely on? How can he build a meaningful project of himself without a reference point? As he is thrown into the world, his existence and the accompanying freedom are meaningless. It is not important what happened, what is happening, or what will happen: "Everything that exists is born for no reason, is prolonged by its weakness, and dies accidentally" (Sartre, 1974, p. 154). The world,

\footnotetext{
4 "When we say that an action has a greater or lesser value, we do not mean that there is a certain smaller or larger distance that separates it from the goal that is always ahead of us [is far away], but one should rather talk about a certain degree the authenticity of one's commitment to achieving his «purpose»" (Lavelle, 1951, vol. I, p. 21).
} 
life, everything that exists and even everything that could exist, appears to be absurd. It is equally absurd to create or not create your own "project" of authentic development.

Realizing oneself fully, that is, being fully authentic, is not possible. Implementation by the existing Self of its own project, as in Sartre, or its own "potential", as in Lavelle, is a process that cannot be fully realized. The question, therefore, remains of justifying this futile or perhaps heroic challenge. Here we can see an important qualitative difference in the choice between recognizing ourselves as a measure of the world and acknowledging the divine dimension of reality. Only by referring to the absolute pattern, regardless of how it is understood, one can construct a project of one's own development. Accepting, as Lavelle does, not as unfounded after all an assumption of our participation "in something", we have some data to create, construct or reconstruct our own image, which we will put into practice - that is, our essence. In Lavelle's conception we can see some points of convergence with the thought of M. Heidegger, who emphasized that "there is no such thing as a man who would be human only by himself" (Heidegger, 1977, p. 251). He also pointed out that "It is not the arbitrariness without the bonds and the bonds of bare acts that constitute the freedom of the free" (Heidegger, 1977, p. 244), but the pursuit of discovering a mystery, whose source transcends us, although it is also "related" to us (Heidegger, 1977, p. 253).

Since "human reality" cannot define itself, Sartre tried to defend the idea by referring to ideal goals. A man striving for authenticity "is a pure choice of his absolute goals. And these goals are: to save the world (by making existence exist), to make freedom the foundation of the world, to undertake creation and to act so that the origin of the world is an absolute freedom that is constantly renewing itself" (Sartre, 1983, p. 463-464). It is only by fulfilling the duty of being through the implementation of these goals that man, according to Sartre, can achieve real existence.

One might wonder why in order to "be yourself" one should pursue such high goals? Of course, we remember that being is not enough, as it must be transcended - in this respect the vision of Sartre is similar to the thought of Lavelle. However, whereas for the latter freedom was a natural, ever-reproducing gift that everyone can use to realize their potential and shape their essence based on it, for Sartre it seems to be a task, a "project" - just like an existing man, who "is also a project himself, and reflection is a project of fulfilling this project" (Sartre, 1983, p. 495). We fall into a vicious circle of intellectual constructions that in no case constitute inspiration for action. The project is a clue for my transcending myself, but reasoning is not sufficient for undertaking it. Reason is able to undermine any project before it is implemented (Sartre, 1983, p. 496). Thus, in this conception, no human-project has a strong enough justification for realizing man's authentic existence.

As the final consequence, "Authenticity discovers that the only valuable plan is to a c $t$ (and not exist) and that the plan of a c $t i$ o $n$ cannot be universal in itself because otherwise it would fall into abstraction (for example, a plan of doing good, always telling the 
truth, etc.). The only valuable plan is a plan to act in the face of a specific situation and strive to change the current state. [...]. In fact, the point is to do what is needed and necessary. So, you have to $\mathrm{c} h$ o o s e between two equally effective routes the one which is easier and allows you to save your strength. If someone chooses the most difficult, it is because they try to exist. So originally, a $\mathrm{u}$ th e $\mathrm{n} \mathrm{t}$ i c i t y means giving up the search for Being because I am always nothing"' (Sartre, 1983, p. 491-492).

Sartre's authenticity ultimately amounts to the affirmation of pragmatic activism. We do not need any sense. No long-term project is possible, also being yourself turns out to be an excessive complication. Why should you search for yourself if it is a vain effort? Freedom becomes its own denial, it is not for me to create myself - it is "more difficult" - but to react to the situation, according to the algorithm of benefits and losses. To be authentic, it is enough to act for action or for convenience, all other choices are unnecessary obstacles to existence. Assuming that already at the starting point "I am nothing", Sartre does not find in his conception the possibility of exceeding this original state. Therefore, there can be only one conclusion - "I am always nothing" and whatever I do, turns out to be an unnecessary energy expenditure, or an unnecessary fantasy of the convict to nothingness of an absurd being-for-itself. What remains? - total conformity to situations in which whatever we do, we choose something (i.e., we are free), however - in accordance with rational premises, with a peculiar economy of existence, we should choose only the easier option. As a result, the concept of Sartre leads to the acceptance of a stress-free, non-reflective "short cut life". But where is the place for creativity that was supposed to constitute the sense of all existence?

Such an escape from any deeper reflection to someone who, like Sartre, was unable to find any sense of existence, seemed to have been the only way out of despair and hopelessness.

For Sartre, authenticity is associated with the search, through existence, for what I have not yet invented about myself. All kinds of knowledge and every project are as good as any other and equally unnecessary. For Lavelle, who saw the value of already realized "nature" and emphasized its necessity as a springboard for our searches, authenticity is the existence of the self, participating in Being, focused on discovering himself, his abilities and on the greatest possible actualization of those discoveries.

In Lavelle's conception, an individual, although aware of being "abandoned in the world, imprisoned in his own loneliness and unable to break it, not knowing his beginning, doomed to an incomprehensible fate and certain of only one thing, namely, that he is sentenced to death, which one day will devour him" (Lavelle, 1947, p. 34), is able discover his participation in Being through reflection and experiencing his own existence. Being calls the self to cooperate in his self-creation, allowing for his fulfillment. Being is at the same time the source, constant support and the goal of the existence seeking himself. The only imperative remains to give ourselves and the world the gifts we have received from Being: 
"man cannot have a purpose other than to become a god for man [and] the only way to repay God for what we have received from Him, is doing for others what He has done for us" (Lavelle 1946, s. 188). In a word, instead of being unnecessary lust (passion inutile), as Sartre sees it, we can be grateful co-creators of ourselves and the world.

\section{The World of Values}

Lavelle's greatest discovery was to see that while a man is a measure of values because he formulates them, at the same time - since his calling is to transcend himself and to be who he is not yet at the moment - there must be some source of existence that transcends him. Lavelle accepted that the call to transcend the measure can only be explained by the existence of a good Being that gives us love. A similar concept of calling to exceed one's "measure" we can find in the works of M. Blondel (1994, p. 125). Thanks to this assumption, in his conception of existence there appears a metaphysical and psychological space, in which I c a n act, because I receive the possibilities, I c a n feel, because I have the ability to feel, experience, want, and love. I c a n think because I am in an intelligent space, thanks to which I can constitute my own "I", and I am a b l e to develop myself.

According to Lavelle, we do not invent or create values. Value exists for the subject, because it is noticeable when the subject wants to possess something. At the same time, it is the value that is the impulse for every action of the self that is formed by consciousness. Emotions are at the source of the discovered world of values. They are the ones that look for values through which they could be expressed. Existence and our reactions to it provide the intellect with material for creating some sketches, temporary projects of further development, but only a few find their calling right away. More often, existence modifies these projects, revealing previously hidden emotions and preferences. Thanks to feeling (le sentiment), the self discovers both the existence of the external world, beings, and things, as well as his own existence of a finite being.

It is worth paying attention to the structure of value which was presented by Lavelle. According to him, all values form a kind of continuum, they are all dependent on each other and make up one Value that embraces particular desires: "The characteristic of value is that it is not given as an object and is not thought of as a concept. Value is what is wanted and because it is wanted, it can always be rejected. However, the theory of value is just trying to show us what can be desired in an absolute way, i.e., always, and everywhere, taking the form of hic et nunc in particular forms" (Lavelle, 1951, vol. II, p. 15).

Thanks to "lower" values, the developing awareness of the existing "self" reveals "higher" values. Material values are the reference point for emotional values, which direct to cognitive values. Knowledge contains an element of contemplation. In turn, aesthetic values, by perceiving the sublime, by feeling the beauty and feeling of joy associated with it, direct 
us towards purely spiritual values. At the highest level of development, the self sees spiritual values, i.e., moral, and religious ones. This is a characteristic feature of Lavelle's thinking he not only looks for mutual relations between various phenomena and problems, but also, in the diversity of all phenomena he shows their complementary unity. Each of the "lower" values is a necessary step in recognizing the higher values, because it already contains the seeds of those higher values. Furthermore, "no value can remain isolated from the others; otherwise, it would transform it into an object, and stop the movement of consciousness instead of stimulating and reviving it" (Lavelle, 1951, vol. II, p. 19). This is the most important imperative of consciousness - consciousness must remain in motion, in constant search, in development.

This movement of consciousness allows to find the meaning of existence: "Man is a being whose existence matters for him, and because a human being is an action, it means that his choice of being at the same time matters to his existence" (Sartre, 1983, pp. 489-490). Through our choices, we give meaning to ourselves and the project that we are to implement. However, for our existence to have meaning, everything that exists, the whole of being, also must have some meaning in which our own meaning could be inscribed.

Sartre's axiological instrumentalism is created on different assumptions. Apart from the project, understood as an ideal goal, there is no other sense, because, in Sartre's opinion, there is no objective order of values. The chosen goal may have sense only if I assign values to it and I will create my own "absolute" order that will allow me to assess my own actions. In relation to the goal, every value remains an auxiliary element, an "optimistic clue" (Sartre, 1983, p. 260), which directs towards a future which is not limited by the past and is a possibility for a human to become a subject. It is not, however, in the full sense of the word, established by being-for-itself, but along with this being it coexists (consubstantielle) (Sartre, 2007, p. 141) and it is established, or rather embodied, by specific choices and actions.

According to Sartre, the value that always appears with a person, obtains its paradoxical $^{5}$, elusive existence only thanks to the existence of man and his freedom. It is what it should be and never just what it is. Its origin can be regarded as parallel to the existence of "human reality", and thus it is either earlier than the individual or at least simultaneous with it. However, its existence depends on specific acts, which is why "value requires deeds, and therefore its realization: it is not enough to love the Good, you still have to do good" (Sartre, 1952, p. 345). The problem in Sartre's concept, however, was the inability to recognize what "good" is, or rather the lack of possibility of finding a "good" other than the good that has been designed by the individual.

\footnotetext{
5 "Value is marked by a double nature (...) which is the nature of unconditional being and not being it. As a value, in fact, value has a being; but this normative existence has no real existence, to be precise. Its existence is a being of value, that is, she is not a real existence. In this way, the existence of value as value is the existence of what has no existence" (Sartre, 2007, p. 138).
} 


\section{Conclusions}

According to Sartre, an authentic man, thanks to absolute freedom, creates himself and his world. For Lavelle, thanks to freedom man can develop his possibilities to the limits of perfection. Existence, which in both conceptions precedes the essence, in Sartre's vision is not determined as long as man frees himself from the determinants that burden him. For him, existence is to reveal the originally secret essence. The obtained possibilities limit its final shape, but also enable discovering it.

Comparing the "existentialism" of Lavelle and Sartre we can label the first as e volution is t and the other as revolution a r y. The first emphasizes the constant connection with the spiritual world, as well as with the values discovered and created in the material world, which are necessary for the development of the self. This second existentialism, on the other hand, accepts and often emphasizes that in order to develop and create itself in a free way, the self at the starting point must be nobody and nothing. The first vision is the apotheosis of hope, the other is its complete denial: "Do not expect morals full of hope. People are mean. You have to love them because of who they might be, not because of who they are" (Sartre, 1983, p. 15).

Sartre's conception is inconsistent: by raising freedom to an absolute level, he imposes his own beliefs on us, claiming that we cannot believe in God. If we were to stick to his assumptions about freedom, we would have the full right to believe, and even if God did not exist, we would still have the full right (free choice) to "call Him into existence" or, if you prefer, "restore Him" to human reality. Anyway, it is difficult to think of any philosophizing without assuming transcendence. It is hard to disagree with Lavelle's words that "Transcendence is what always surpasses me, but I can never stop receiving from it" (1946, p. 150).

In pluralistic societies, dealing with the problems of the coexistence of very different cultures on a daily basis, with an increasing number of previously unknown problems and with the need to develop new norms, there is an increasing need for a reflection that would not be focused solely on the question which values allow the best kind of life. There remains an important problem: how can I experience the diversity and complexity without giving up my own identity? In the new reality, we need to create a model of social life from the scratch. Lavelle's pluralistic axiology could be helpful here.

Lavelle makes one think that the desire to grow is and should be the source of optimism. Both individual and community life, connected with making choices, make sense only when they are elements of existence, the meaning of which is not just a series of fulfillments, but is illuminated by joy, which successively develops and purifies actions and reflections. The goal of Lavelle's philosophy was to provide man with faith in his abilities, which, together with hope and self-esteem, would restore his confidence - first to himself, 
and then to others and the world. It seems that this model of existentialism can be a better basis for creating contemporary human reality than the model proposed by Sartre.

\section{Bibliography:}

Bergson, H. (1904). Données immediates de la conscience, Paris: Félix Alcan.

Blondel, M. (1994). Filozoficzne wyzwania chrześcijaństwa, [Philosophical Challanges of Christianity]. Trans. J. Fenrychowa. Kraków: Znak.

École, J. (1952). L'Existencialisme de Louis Lavelle, Revue Thomiste, LII (2).

Heidegger, M. (1977). Pytanie o technikę, [The Question Concerning Technology], Trans. K. Wolicki, (in:) M. Heidegger, Budować, mieszkać, myśleć. Warszawa: Czytelnik.

Lavelle, L. (1946). De l'Acte, Paris: Aubier.

Lavelle, L. (1947). De l'Etre, Paris: Aubier.

Lavelle, L. (1948). Les Puissances du moi, Paris: Flammarion.

Lavelle, L. (1951). Traité des valeurs, Paris: Les Presses universitaires de France.

Lavelle, L. (1955). De l'intimité spirituelle,Paris: Aubier.

Nietzsche, F. (1907). Antychryst, [The Antichrist]. Trans. L. Staff. Warszawa: Jakób Mortkowicz.

Nietzsche, F. (1907). Wiedza radosna, [The Joyful Wisdom]. Trans. L. Staff. Warszawa: Jakób Mortkowicz.

Nietzsche, F. (1911). Wola mocy, [The Will to Power]. Trans. S. Frycz, K. Drzewiecki. Warszawa: Jakób Mortkowicz.

Sartre, J.-P. (1944). Mise au point, Action [29 December 1944]. After: École, J. (1952). L'Existencialisme de Louis Lavelle, Revue Thomiste, LII (2).

Sartre, J.-P. (1952). Saint Genet, comédien et martyr, Paris: Gallimard.

Sartre, J.-P. (1974). Mdtości, [Nausea], Warszawa: PIW.

Sartre, J.-P. (1983). Cahiers pour une morale, Paris: Gallimard.

Sartre, J.-P. (1998). Egzystencjalizm jest humanizmem, [Existentialism is Humanism], Trans. J. Krajewski. Warszawa: Muza SA.

Sartre, J.-P. (2005). Morale et Histoire, Les Temps Modernes: Notre Sartre, 632-633-634 (juilletoctobre).

Sartre, J.-P. (2007). Byt i nicość, [Being and Nothingness], Trans. J. Kiełbasa, P. Mróz, R. Abramciów, R. Ryziński, P. Małochleb. Kraków: Zielona Sowa.

Truc, G. (1946). De J.-S. Sartre à L. Lavelle ou désagrégation et reintegration, Paris: Tissot.

Zuziak, W. (2012). Aksjologia Louisa Lavelle'a wobec ponowoczesnego kryzysu wartości, [Axiology of Louis Lavelle in the Face of the Postmodern Crisis of Values], Kraków: WAM. 